\title{
Branding in a Contemporary Business Environment: A Case Analysis of N.V. Soeng Ngie \& Co in Suriname
}

\author{
Kesia Marengo* \\ China \\ *Corresponding Author: Kesia Marengo, China

\begin{abstract}
The purpose of the paper focuses on the brand positioning of N.V. Soeng Ngie \&Co, a Chinese distribution company in Suriname.

A research assessment of the brand N.V. Soeng Ngie \& Co is conducted to analyze the communication aspects of a brand. The results of these analyses comprehend that the brand brought social awareness of Chinese products. It contributed to the social development of the society through food products. As a result, it developed unity among the Chinese community and Suriname's society. Furthermore, the brand image interacted with its consumer's emotions using their sense of taste and appealing culture of the society. The brand loyalty towards its customers is solely on providing quality products.
\end{abstract}

Moreover, the brand marketing strategy remained unwavering and strategically focused. The case study analyses demonstrated two communication models based on how the consumers intercept the brand's message and how it convinces a consumer purchase behavior; therefore, the use of Harold Lass well, the $5 W$ Communication model demonstrating brand intercedes with the consumer. The use of the two-step flow theory projects how the brand message channels through mass media and are then interpreted by opinion leaders and further transmitted to consumers. Demonstrating brand communication channels influencing consumers.

Keywords: Brand Management, Brand Image, Brand loyalty, Brand Positioning, Marketing Strategies, N.V. Soeng Ngie \& Co

\section{INTRODUCTION}

A brand is a unique design, symbol, or word of a combination that creates an image that symbolizes a product and differentiates it from its competitors. It gives a product tremendous value, and it connects to emotions and feelings; it is an intangible source that has been given great interest to humans (Tanya, 2015). A brand stands out as just a non-generic name for a product that informs consumers of the product's source. It emphasizes the quality and services the company has to offer to the public society.

While it generates a tremendous increase in customer brand loyalty, it offers a profit margin and is a defense for competitors. An organization's brand signifies a great prospect of"' consumers' feedback and interest in how they think and hear of a"' company's brand. Scholars indicate that organization or company brands are a direct consequence of the strategy of market segmentation. The uniqueness and the diversity of the brand display prominent interest for consumers and prospective business partners (Hunt, 2004). Branding a company means more than just giving a name and signaling to the outside world about a product or service stamped with an organization's imprint. Branding consists of transforming the product category, which requires a corporate long term involvement, and a high level of resources and skills (Tanya, 2015). Therefore, it creates opportunities for companies like N.V. Soeng Ngie \&Co to establish a formidable brand. Suriname today has invested a lot in, importing, exporting goods and services, and others imported from the USA, Hong Kong, and Thailand. The company Soeng Ngie \& Co supplies the Surinamese society with authentic and unique products such as sauces, powders, and herbs from China.

The services of their products linked the gap between the Chinese community and the multi-ethnic Surinamese society. Besides, the company added its touch and values to what Chinese products had to offer to the Surinamese society. The exceptional brand products such as black Soya sauce, Lee, Kum Chin sauce, chicken powder, and Shiling oil, provided users with excellent experience in preparing the delicious dishes and treatment to health illnesses. The firm maintains its position in society by 
offering various Chinese products options through different means of attraction. The company determination in its brand is displayed in its operation in research and its usefulness in marketing strategies. Its strategic process portrays the process of how the brand communicates with its consumers. It is the way of delivery of the brand message that creates an exchange offers of the brand products is what creates the brand value fo customers, partners, and society in general.

A brand aspect that differentiates the organization's products directly and indirectly from its competitors. A company's brand objective is to ensure its position in the market platform and its position within the'" consumer's mind. Their brand products have reliable attributes that the company engraved in its consumers' minds as a recall factor. This article explains the concept of brand positioning strategies by N.V. Soeng Ngie \& Co as the first Chinese importer and distributor of Suriname goods and services. The paper consists of two parts: the first part is about the brand of the company, and its products explained in detail all theoretical aspects focused on the brand. The second part is based on an analytical case of the company. The paper's analytical aspect contextualizes the perception of how brand communication has an influence on consumer purchase behavior and how the consumer intercepts the message of the brand.

\section{N.V.SOENG NGIE \& Co.}

N.V. Soeng Ngie \&Co started with the first generation of Fung You Kee, who came to Suriname with the last boat as a contract worker. Mr. Micle Fung You Kee is from Canton (present-day Guangzhou). $\mathrm{He}$ and his older brother and thirty of his friends left China to find their great fortune in Suriname. Mr. Micle Fung You Kee first worked as a contract worker on the plantations, then as a watchmaker. $\mathrm{He}$ later started to sell items such as onions and garlic on a bicycle on Paramaribo, the capital city of Suriname. He used his wits and ways to make an image for himself within society usingabicycleandsomemeaslyproducts.Peoplegotfamiliarizedwiththeproducts sold to them by the company's brand, and it is products. During that age, the brand image of the company positioned itself among the people. It made a connection with them due to the brand exotic products from a foreign country like China.

The establishment of the brand image made the company work on brand loyalty. The quality of the product remained positioned within the consumers, which remained unique as the only brand known to society. It accomplished this achievement through the early promotion of coupon deals in the 90 s to make their product wanted and known to the public. The company's advantage is the first, and it had enough support of the government to exploit various resources. The resources that aided the company are television broadcasting, radio, and poster to promote the brand and recognizable to its customers.

The brand specialized in importing and distributing products from China, Hong Kong, Taiwan, Indonesia, Thailand, and the United States of America (USA) (Miguel Fung You Kee, 2020). The company is the sole representative of the brand products such as Cock Brand powder, Geliga or Balsam Otot spread, Formula toothbrush, and Shiling Oil spread (Miguel Fung You Kee, 2020). Due to the company management, it made sacrifices to sustain the brand, by sending someone to intercede between China and Suriname to make this company brand flourish in what it is now (Miguel Fung You Kee, 2020). The company sacrifice for the brand establishment created an unwavering position in society and an unshakable loyalty foundation against competitors.

Moreover, the company's mission is closely related to what a brand stands for and its purpose. The mission of the brand N.V. Soeng Ngie \& Co set itself the goal of expanding the company in ways unimaginable form a store to a trading company. The company is not only locally known but also regional and even in Europe (Miguel Fung You Kee, 2020). Its focus was to create a brand known by locals; instead, the brand became more than what it was intended to be a brand known to many. The achievement based solely on the products or the way the brand communicated with the audience and how the audience perceived ensured that this brand has become successful in the market platform.

\subsection{Brand Positioning}

Brand positioning is a space a company acquires in consumers' minds and how it differentiates itself from its competitors. It is a marketing strategy tool that aids businesses in setting themselves apart from other competitors (Belch, 2001). N.V. Soeng Ngie \& co occupied the minds of its consumers' by using the smallest goods of Chinese products, starting with a pack Adjee - Na - Moto from China to 
season chicken. The company insinuates its consumers by using Soeng Ngie \&Co products in every homemade dish that guarantees the food will be splendid. The company positioned itself in society's hearts with a brand positioning statement by thoroughly researching its diverse ethnic population. Therefore, the brand positioning statement is a description of the business target market that includes a holistic picture of how the business likes its brand to be perceived by customers (Belch, 2001).

The brand intends to ensure consumers that the product that they buy is guaranteed. That the brand's product is an essential part of the customer's lifestyle, and it distinguishes itself as the first in the market to promote the various food products of China. Hence, it provides the consumers with the brand essence that communicates with the desire and needs they can satisfy. The brand shows it is unique, and consumers can benefit from what it provides them and that it pertains to the values of the subculture of its product projected to its consumers. The Soeng Ngie \&Co has pertained to the essence of its brand in society. However, it has market positioned itself with its main objective is influencing its consumers' perception with a clear, unique, and advantageous position against all competitors.

\subsection{Brand Image}

The brand positioning distinctly describes the position a brand has in the mental concept of a consumer. The context of positioning a brand is on how a brand positions itself within the consumer's mind, which explains how consumers perceive the brand image. This way, a brand's image or the mirage of the brand plays a role in consumer purchase behavior in patronizing the brand products. The brand image is the customer's perception of the brand based on their interactions. It can evolve, and it does not necessarily involve a customer making a purchase or using the brand's products and services (Kaemingle, 2019). Since customers can have a different opinion on a brand, organizations must work hard to maintain a consistent brand image. Nowadays, consumers, especially the new generation of the technology era, do not purchase products for only their quality but also purchase a product solely for what the brand stands for. Most companies link the focus only on the interaction of a brand purchase in quantities but that the quality of the company's product matters more than the quantity. Soeng Ngie\& Co has made a clear perception of their target market by having the product interact with what human beings love most in life and desire.

Through food, the brand image of the company focuses on the image of food products. The interaction of food products and images of delicious food convince consumers to long and question what makes these food products of the brand so exotic. The food products of the company created a display that justified its image as a brand. As Kotler (1988), in Meenaghan (1995), explained, a brand image set of customers believing towards the brand (Malki, 2015). Consumers purchase a product or brand based on how they feel, see, interact, and connect with a product. Dobni and Zinkan (1990) stated in Cho (2011) that a brand's product is choices based on a consumer's perspective, feeling, or attitude towards the brand image (Malki, 2015).

Further, the company's brand image interacted with its consumers. It provided them a belief and a personal interaction through the color images of delightful food dishes.

The brand food products ensured a connection between the brand image and its consumers.

\subsection{Brand Loyalty}

The brand positioning is the brand placement in the mind of its consumers, and the brand image is the interaction a consumer has with the brand. Brand loyalty is the positive association consumers attain to a particular product or brand. The consumers express brand loyalty by demonstrating complete devotion to the brand's particular product or services (Kopp, 2019). N.V. Soeng Ngie \& Co connected with its consumers from the beginning by merely winning their loyalty. Through their Chicken powder and Leem Kum Kee sauces that came with excellent customer services in society's preference. Like earlier researchers, they suggested that loyalty is that" customer loyalty is an in-depth held commitment to rebuy a preferred product or service of the brand consistently in the future. Despite influences and marketing efforts having the potential to cause switching behavior" (Hofmann.N \& Frankfurt am Main: Peter Lang AG. March 1, 2013, p. 392). The company's brand made a significant impact and change in consumer behavior in purchasing its products. It continually pressed on in making the society believe and trust in their products. It proves to society that the brand is trustworthy and "A" quality; it provided the essential aspects for the preference of their consumers' pallet. A brand 
gives a clear expectation about its product's intention, not only a product the consumers believe in and trust. A brand that contributes to its multi-culture intention in preparing their dishes (Miguel Fung You Kee, 2020).

\subsection{The Marketing Strategies and Positioning of the N.V. Soeng Ngie \& Co Products}

To further comprehend the brand positioning, image, and loyalty, about a brand's product perception perceived by consumers. It is better to understand brand marketing strategies and how the company uses its brand to increase its products.

First, is the marketing strategy; this is a full plan for a brand to achieve its marketing objectives. A marketing strategy is a well-articulated tool that enables one to focus on brand marketing activities to achieve the organizational goal (Chavan, 2014). It is the marketing tool process that a company acquires to make its resources useful so that it aids in sales production by achieving a sustainable competitive advantage.

The market strategy's central concept is customer satisfaction as a goal. The brand positioning, image, and loyalty are all based on the perception and imprint the'" company's brand has on its consumers' mindset. Besides, that positioning of a brand explains the strategy. It insinuates the'" company's use of brand positioning, image, and loyalty to make these aspects successfully interpreted by the target market of the company. It further defines positioning on how an organization uses its market strategy to make a brand stand out and occupy a distinct position with other competing brands by offering similar products and services in the market place and their consumers (Mair, 2007). This strategy makes a product unique and makes users consider using its distinct benefit; it features the brand (what it is, what it does, and how it functions). Therefore, it provides the product a USP (Unique selling proposition). A perfect and good position in the consumers' mind allows the product of a company to stand against hard times more efficiently. It allows the company to be more flexible with the brand or product in ways such as extensions, changes, distribution, and advertising.

The organization's implementation of positioning is through the marketing mix the"' 4P's (product, price, promotion, and place). The"' 4P's state a clear focus on how businesses benefit from being positioned as a brand towards its prospective consumers. However, a brand should be first and foremost unique, and its position must be defensible and, therefore, positioning requires making choices. N.V. Soeng Ngie \& Co is the first successful positioning Chinese brand in Suriname. The company went thorough research on identifying the uniqueness of a multi-ethnic culture society. The company took initiatives to understand their consumer's different preferences and what the company can offer such consumers and how to ensure that the brand is capable of standing against upcoming competitors. Thus, its position as a brand reflects what the company stands for. As a result, N.V. Soeng Ngie \& Co has become more creative in its marketing strategies in providing consumers quality products that are reliable and trustworthy. The products and the brand provide a suitable image for consumers to create ways of advertising and broadcasting amazing shows in the interest of its consumers nationally and internationally. The companies brand positioning in the society ensured difficulty for other competitors to reposition it without destroying its credibility and its years of hard dedication to building brand loyalty.

\section{MARKETING MiX}

The use of the marketing mix can only be fully comprehended to describe how the company uses the brand to its target market. It is a tool used in the advantage of making the brand of a company stand out. It provides insight into a specific area of the brand's downfalls. It improves in such pitfalls in the future marketing strategy of the brand. Its reference to the marketing mix is a set of actions or tactics a company uses to promote its brand product. It includes strategic decisions about the product (core, actual, augmented), the price it cost the consumer to get the product, and the place the product offers. The way to promote the brand product to the target audience is with the useful implementation of a strategic marketing mix (Thackeray, 2007).

The products of N.V. Soeng Ngie \& Co is the first successful Chinese company in importing and distributing Chinese food products to almost 400 stores in Suriname (Miguel Fung You Kee, 2020). The company offers good pricing deals for its products to retailers, stores, and consumers. 
Furthermore, it has a fast distribution strategy that makes it easy for consumers to purchase their products at local stores. The brand products are in the official language, translated to the preference of its consumers.

N.V. Soeng Ngie \& Co offers different pricing strategies based on the different values of the product. The products' prices vary; they do provide their customers with promotional discounts on certain special days. Special occasions such as mother's day, father's day, and national holidays offer great pricing deals. Further, the company has its promotion deals that create a pole increase in sales for their product. There are also various payment options available for consumers, like using cash, vouchers, and pin card.

The place of the company has a showroom and stores in the city center of Suriname. The brand has four open warehouses and distributes its products to all stores in all regions nationally and internationally countries like Guyana and other Caribbean countries. Nevertheless, the products are even in the Albert Hein stores in Amsterdam, Netherlands. The brand's promotion is through the live cooking show and fitness workout on TV channels of Suriname; it uses commercials and banners to connect with its consumers. Besides, it even makes use of social media such as Facebook, Twitter, and their website. The effective way of promoting the brand is through" Mofu Koranti," also known as nostalgia (Miguel Fung You Kee, 2020). However, this increases the brand popularity among the society they use this popularity to sponsor plays in theatres and engages with the society by joining the Easter Carnival yearly.

\section{SWOT ANALYSIS}

As the marketing mix, the SWOT analysis is a tool to aid the company in its Strength, weakness, opportunities, and threats. Moreover, so that the brand can withstand threats and advance in future opportunities, using such a tool is useful to any company that wants to make their brand well known to their target market. The SWOT analysis is a tool used by organizations for strategic planning and management in using to build an organizational and competitive strategy against future threats. In other words, a "SWOT Analysis is a simple but powerful tool for sizing up an'" organization's resource capabilities and deficiencies, its market opportunities, and the external threats to its future" (GÜREL, August2017).

The Strength of the brand has a reliable customer database to rely on their product to produce sales. Without a doubt, the products ensure their consumer's quality and reliability. The management of this firm devotes to making every product successful in the market. The brand provides confidence for the firm and its consumers; moreover, product dominance in society's market creates durability for the company. It is an experienced company from being a store to an import and distribution company, which remained one of the top brands that evolve with society.

The brand's weakness is its reaction to specific gaps, such as agile marketing and advertising strategy. Every marketing strategy needs to evolve all members of the company's decisions. Nevertheless, some of these members are already in their prime age, consequently hard to convince to adapt to change involving marketing decision making. Going international requires more warehouses ordinarily that require more finances, whereby the prices of the products increase in the stores.

The brand's opportunities have an inferior product competition since the other distribution companies are not very creative. The competitors use the same products against the firm to win over the consumer; instead of creating the uniqueness of their products to the market platform. Further, the company provides the market always with new products from China. As such, China is the brand never-ending well for promoting new Chinese food products. The firm is agile on market response and stands in a high-profit margin compared to its competitors.

The company's threat is not the only player in the import and distribution sector; there are plenty of competitors. National politics plays a role in affecting the firm through import taxes, product taxes, and advertising taxes. Furthermore, it causes an increase in product pricing, consequently also a decrease in the revenue of the firm.

Therefore, customers will find other alternatives replacements. Moreover, the political movement also affects the value of the currency. The devaluation of the country's currency can put the firm in debt and a decrease in sales. 


\section{Case Analysis}

This case analysis explains the possible marketing strategies used for the brand N.V. Soeng Ngie \& Co to communicates its message to its audience. The use of Harold Lass well's $5 \mathrm{~W}$ communication model will demonstrate the brand's communication and objectives. It comprehends how to define what the consumers receive and interact with the company's product. However, the use of Lazarsfeld and Katz's two-step flow communication describes how a product is being transmitted and projected by opinion leaders and further transferred to followers. It imitates the brand way of communication through the rest of the society; this creates an image that signifies a product and differentiates it from its competitors. Besides, it gives a product of enormous value, and it connects to emotions and feelings, it is an intangible source that has aroused great interest in human beings.

The main marketing theories involved in this case include:

\section{Harold Lass well's "5W" Communication Model.}

Harrold D. Lass well was the most impressive and creative innovators in the Political and Social Sciences that have ever lived in the twentieth century. In 1948, he developed a communication theory, recognized as "one of the earliest and most influential communication models. "The Structure and Function of Communication in Society" Muth, 1990 described the actions of the $5 \mathrm{~W}$ communications conveniently to answering the following questions:

Is the "Who," the "Say What," "In which channel," "To whom," and "With what effect."

Further, the communication model projected how to persuade people through certain types of media communications' action plays a vital role in the aspect of people's way of thinking and reacting to information.

\begin{tabular}{|c|c|}
\hline Who? & - Who is initiating and guiding the communication \\
\hline What? & - The content \\
\hline Via Which Channel? & - Television, radio, press etc. \\
\hline To Whom? & - People reached by the communicator \\
\hline To What Effect? & - Impact upon the audience \\
\hline
\end{tabular}

Fig1. Illustrates the Harold D. Lass well 5 W communication model.

a. "Who" refers to the initiator or communicator who formulates the message. The initiator refers to the brand N.V. Soeng Ngie \& Co food products, which are Chinese sauces, chicken powder, and pickled fruits.

b. "Say What" refers to the content of the message. In this case, the message's content refers to the benefits and quality of N.V. Soeng Ngie \& Co food products.

c. "In which Channel" indicates how the message is being communicated and transmitted? In this case, diversified channels are used, such as Television broadcasting, a live cooking show, and fitness shows. The live broadcast channels demonstrate delicious healthy eating lifestyle dishes prepared with the brand products. The transmitted message intercedes through radio and newspaper channels to promote brand products. The company brand message then conveys to the audience the brand products sale promotion and N.V. Soeng Ngie Street event demonstrated at the Chinese Sunday market. With the evolution of technology in recent years, different channels are useful to transmit the message through channels such as the company's website, Face book, Twitter, and YouTube commercials. 
d. "To Whom" describes to who the intended message is to either an individual or an audience. In this case, such individuals/audience refers to the society of Suriname.

e. A focus group, the company, targeted is the housewives, caterers, and chefs that prepare daily meals for their family, customers, and clients. Transferring and communicating a message that the products of N.V. Soeng Ngie \& Co are essential in preparing dishes. Further, these products are an "A" quality product that suits every palate preference, either sweet or salty. The brand demonstrates the reliability of its product and the various options a consumer has acquiring the products of N.V. Soeng Ngie \& Co. Diversified channels on social media website cookies notify the company advertisers, what the likes and dislikes are. The company then places its ads on websites, Face book, and other social media platforms that tailor to their focus group.

f. "With what effect" refers to the outcome and reaction of the message after requiring it. How the individuals/audience reacts and behaves toward the message? The use of diversified channels such as Television and radio, in the beginning, gave the brand not a justify assurance that the brand was received. The company's promotion and events usually have commission researchers in the field to find out how well-known the brand is whether its message impacted the public. With new technology and media, it made it accessible for the company to find out if the brand is in the preference of society. The company website and Facebook, Twitter ensures the companies whether people favor the products of N.V. Soeng Ngie \& Co. As a result of this, people's comments and remarks are useful for improving the brand's marketing strategies.

\section{Lazarsfeld and Katz Two-Step Flow of Communication Model}

The sociologist Paul Lazarsfeld introduced the two-step flow of communication model hypothesis together with Bernard Berelson and Hazal Grandet in 1944. This theory tested in the 1940 presidential campaign, the results of this theory published in "The People's Choice "paper. Moreover, the two-step theory model focuses on people's opinions influenced by opinion leaders; then again, opinion leaders influenced by mass media. (Lazarsfeld, 1955)

However, opinion leaders transfer their information to their less active associates, over whom they have influence. Moreover, the audience of these opinion leaders then digests this information. It diminished the mass media in the researchers' eyes that causes the conclusion that the social factors are an essential aspect of how the audience interpreted text, messages, and information. Further, it confirms the theory that information flows from radio, TV, print (newspaper), and social media to opinion leaders (influencers) and then to the rest of the population.

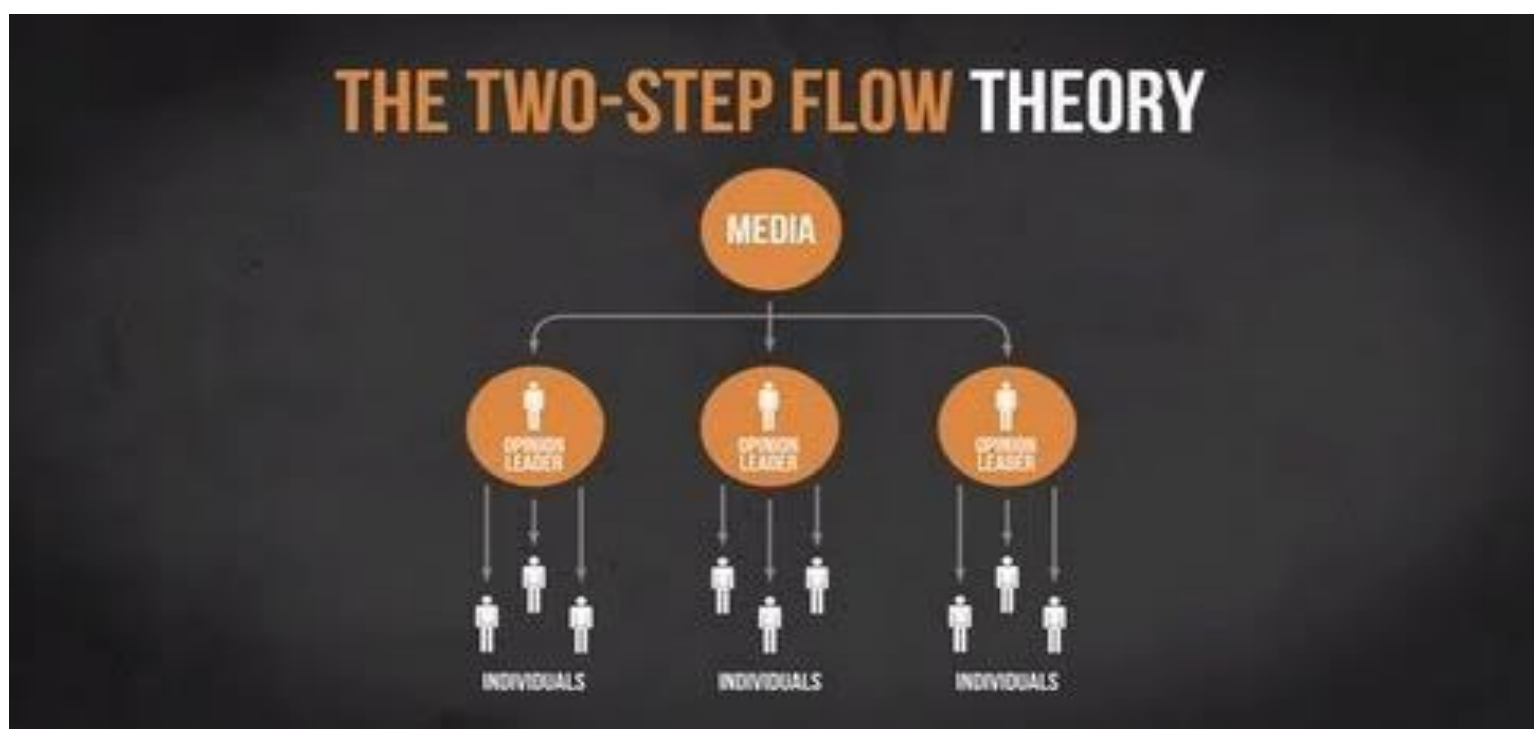

Fig2. Illustrates the Lazarsfeld \& Katz "The Two-step flow theory model.

The two-step flow theory theorized that mass media are having a significant impact on people through information broadcasted. Whereby people digest the information like a drug and just run with the statement mass media makes them believe this interprets the two-step flow theory. (Lazarsfeld, 1955)

1. Mass Media: The mass media refers to diverse multiple media technologies that reach a broad 
audience through communication. However, with technology evolution, it takes communication through another level; therefore, it passes the information through various electronic media. Social media is a new advancement of a marketing platform that has changed the way of mass media. In this electronic era, companies have to adapt to social media marketing to reach their consumers. Therefore, N.V Soeng Ngie \& Co as a brand adapted with the evolution of mass media communication. So that the brand communicates with the people through social media such as Face book, Twitter, and YouTube to stay connected to their audience and not only by transmitting information on TV and Radio stations. However, the brand's product remains seen on cooking shows and a fitness show.

2. Opinion leaders: These are people actively following the media and interrupting the meaning of the information in their way. They then transfer this information to the lower-end media users. In the 90 s, opinion leaders were likely to be change-makers in the society like politicians, freedom fighters, democratize, and riot leaders. Nowadays, opinion leaders categorized as anyone using social media platforms with the era of social media. Therefore, any social media platform can be useful to relay opinions to a broad audience without restriction. These social media platforms include Twitter, Face book, YouTube, Instagram, Bloggers (E-news, Fashion, and tabloids), TikTok, and influencers (models, actors, singers, NBA players). All these channels of media hold tremendous power influence on consumer purchase behavior.

3. N.V. Soeng Ngie \& Co has its influencer, their famous chef, and the host of the cooking show Mr. Micle Fung Yon Kee. An in-house influencer and social media platform are one of the company's tools to promote their variety of products. However, as the host chef, he then co-hosts its cooking shows with the country's well-known singers and chefs. To demonstrate their cooking skill but also use their platform to reach potential customers. By giving a show that illustrates cooking skills and the promotion factor of introducing new products and enticing the audience with inclusive packages of N.V. Soeng Ngie \& Co products. Further, the brand uses all forms means necessary to reach all its audience even internationally through comedian platforms. Therefore, the message of N.V. Soeng Ngie products will transfer to not just Suriname society but to all that are interested in Chinese food products.

4. Audience: The audiences are the people or society which receives information from different communication channels. Whether it is TV, radio, and social media, information transferred to the people they decide whether they take in the information or ignore it. However, N.V. Soeng Ngie \& Co products reach their audience, which cooks to convince them that their product is essential in the preparation of their dishes.

\section{CONCLuSion}

The research analyses of brand positioning within the consumer mind insinuate that a strong brand has a remarkable influence on consumer purchase behavior. The communication theory analysis, findings have shown how a brand communicates and transmits to the audience. The processes of a brand message can be the cause of consumer purchase behavior. It all depends on the company marketing strategies on how effective they can communicate their brand to their designated target audience. Companies worldwide have made great use of all kinds of communication channels to make their brand as persuasive as possible so that the consumer can purchase the brand products.

Over the years, the use of communication channels varies from radio to Television, from Television to the internet platform known as social media. The social media platform made it quite convenient for companies nowadays to influence consumer's purchases. It also has a significant advantage influencing the brand to the extent that consumers psychologically have a total mind shift and are loyal to just that particular brand. The use of the two-step flow theory signifies that all brand communication is broadcasted through any form of channels are then tailored messages made by the company. These messages of the brand are interpretation influence that the company wants to let its audience perceive about their brand. That indicates the message a consumer receives is fabricated on what a company makes the consumer believe. The brand ensures the company a position within the consumer mind. It is either through a jingle of a song or an animated video clip; the focus is that the brand message is transmitted and perceived to its optimal potential. 
A position of brand mentally ensures companies that the brand's message has not only been transmitted but has been conveyed in the unconscious mind of its consumers. However, the way the company brand communicates to its audience revolves around its marketing strategies and which channels it finds useful to communicate its brand to its audience. Further research development should be based on the psychological impact of how a brand communicates with its consumer is therefore recommended. The development of this research will give up-to-date information on the psychological impacts a brand may have on consumer purchase behavior. The research-based on the psychological background of brand communication gives insight into whether a brand influences a specific brain area of the consumer. If the brand influence initially causes consumer purchase - not to purchase unnecessary items base on what they need just because they want.

Does the brand influence on the consumer mind control indicate an effect on the consumer socialpsychological state of mind? The research will help understand if brands influence to change the whole social-psychological character of a consumer, not only purchase behavior but also individually. Can brand influence be the cause of low self-esteem within the mind of the consumer? The research of this question is based on the way the brand communicates through influences, and if they are also the cause of modern consumers' low self-esteem issues. Further, can the excessive brand influence trigger the human brain to result in a psychiatric breakdown? Such research should focus on understanding the extent to which brand communication can cause a psychiatric breakdown. As a result, purchasing brands will be like "an addiction," and it would be hard for persons to get off such a purchasing habit, which might cause a psychiatric breakdown.

\section{REFERENCES}

[1] Tanya, S.-B. (2015). Brand and Branding. Brand and Branding, https://www.researchgate.net/publica tion/272184078_Brand_and_Bran ding/citation/download.

[2] Hunt, S. \&. (2004). Market Segmentation Strategy, Competitive Advantage, and Public Policy. Australian Marketing Journal.

[3] Tanya, S.-B.(2015). Brand and Branding. Brand and Branding, https://www.researchgate.net/publication/2 72184078_Brand_and_Bran ding/citation/download

[4] Miguel Fung You Kee, G. M. (2020, January 31). N.V. Soeng Ngiei \& Co. (K. Marengo, Interviewer)

[5] Miguel Fung You Kee, G. M. (2020, January 31). N.V. Soeng Ngiei \& Co. (K. Marengo, Interviewer)

[6] Miguel Fung You Kee, G. M. (2020, January 31). N.V. Soeng Ngiei \& Co. (K. Marengo, Interviewer)

[7] Belch, G. E. (2001). Advertising and Promotion: An Integrated Marketing Communication Perspective, 5th edition. New York: The McGrow-Hill Companies.

[8] Belch, G. E. (2001). Advertising and Promotion: An Integrated Marketing Communication Perspective, 5th edition. New York: The McGrow-Hill Companies.

[9] Kaemingle, D. (2019, June 12). qualtrics. Retrieved from qualtrics: www.qualitrics.com

[10] Malki, O. (2015). Definitions of Brand Image. Journal of BrandImage.

[11] Malki, O. (2015). Definitions of Brand Image. Journal of BrandImage.

[12] Kopp, C.M. (2019, September 11). Investopedia. Retrieved from Investopedia:www.investopedia.com

[13] Hofmann.N, \& Frankfurt am Main: Peter Lang AG. Retrieved March 1, 2. (2013). Loyalty. In Loyalty Schemes in Retailing: A Comparison of Stand-alone and Multi-partner Programs, 392.

[14] Miguel Fung You Kee, G. M. (2020, January 31). N.V. Soeng Ngiei \& Co. (K. Marengo, Interviewer)

[15] Chavan, A. S. (2014). Chapter 5 Marketing Strategy. In A. S. Chavan, Developing Marketing strategies for enhancing the use of Solar Energy products (pp.74-89).

[16] Mair, V. (2007). Positioning. In the Art of War: Sun Zi's Military Methods(pp.88-90). New York: Columbia University Press.

[17] Thackeray, R. N. (2007). Developing a promotional strategy: Important questions for social marketing. Health Promotion Practice.

[18] Miguel Fung You Kee, G. M. (2020, January 31). N.V. Soeng Ngiei \& Co. (K. Marengo, Interviewer)

[19] Miguel Fung You Kee, G. M. (2020, January 31). N.V. Soeng Ngiei \& Co. (K. Marengo, Interviewer)

[20] GÜREL, E. (August 2017). SWOT Analysis: A theoretical Review. The Journal of International Social Research, 995.

[21] Muth, F. \&. (1990). (Lasswwell, Harold (1948), Bryson. L. Ed. (New York: Institute for Religions and Social Studies). The structure and function of communication are society the communication ideas. 
Branding in a Contemporary Business Environment: A Case Analysis of N.V. Soeng Ngie \& Co in Suriname

[22] Lazarsfeld, K. \&. (1955). "Personal Influence." New York: Free Press.

\section{AUTHOR'S BIOGRAPHIES}

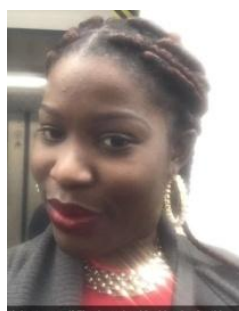

Kesia Marengo, was born and raised in Paramaribo, Suriname. She is an individual that loves art, music, and swimming. Successfully acquired a Bachelor of Science in Administration degree from Suriname Institute of Management Studies (SIMS). Further, she is a hard-working student and is in persuit of her master's degree at Shanghai University. The acquire pursuit of a master's degree is to gain more knowledge and use this vast proficiency in her furure career in Business and Finance.

Citation: Kesia Marengo. "Branding in a Contemporary Business Environment: A Case Analysis of N.V. Soeng Ngie \& Co in Suriname" International Journal of Managerial Studies and Research (IJMSR), vol 8, no. 8, 2020, pp. 10-19. doi: https://doi.org/10.20431/2349-0349.0808002.

Copyright: (C) 2020 Authors. This is an open-access article distributed under the terms of the Creative Commons Attribution License, which permits unrestricted use, distribution, and reproduction in any medium, provided the original author and source are credited. 